\title{
Natural-Geographical Zoning and Geo-Ecologiacal Problems of Georgia's Black Sea Coas
}

\author{
Melor Alpenidze $^{1}$, Zurab Seperteladze $^{2}$, Eter Davitaia $^{2}$, George Gaprindashvili ${ }^{3}$, Tamar Aleksidze ${ }^{2}$ \\ ${ }^{1}$ Sokhumi State University, Department of Geography, Tbilisi, Georgia \\ ${ }^{2}$ Ivane Javakhishvili Tbilisi State University, Department of Geography,Tbilisi, Georgia \\ ${ }^{3}$ National Environmental Agency, Department of Geology, Tbilisi, Georgia \\ Email address: \\ Melor07@mail.ru (M. Alpenidze), zura_sep@mail.ru (Z. Seperteladze), gaprindashvili.george@gmail.com (G. Gaprindashvili)
}

\section{To cite this article:}

Melor Alpenidze, Zurab Seperteladze, Eter Davitaia, George Gaprindashvili, Tamar Aleksidze. Natural-Geographical Zoning and GeoEcologiacal Problems of Georgia's Black Sea Coas. American Journal of Environmental Protection. Special Issue: Applied Ecology: Problems, Innovations. Vol. 4, No. 3-1, 2015, pp. 58-66. doi: 10.11648/j.ajep.s.2015040301.20

\begin{abstract}
The region's natural geographic zones meant detection and mapping of Geo-complexes of Identified taxonomic rank. Geo-complexes - Individual territorial units differ from one another by natural conditions, landscapes hypsometry location and their spatial distribution, geo-ecological problems, shape and scale of anthropogenic impacts and extent of the character and quality of agriculture. Interest of Geo-ecological problem of the Region is caused by Black Sea (within Georgia) coast nature use process, utilization of the dynamic equilibrium potential faults. Negative changes in the functioning of natural systems and the disorder lead to unwanted changes. Possible solution to the problem of ecological science and environmental components geo-complexes scientific studies based on geographical and ecological aspects of the current state estimates, analysis and forecasts. Research object: Black Sea coastal zone - the eve of the land and sea include three geomorphological elements: coastline, beach and underwater slope. It is obvious that the acute deficit of sediment to the main geo-ecological problem even worse by strong anthropogenic pressure, which in turn is connected with the region's natural resource potential (Resort-recreational, Balneology, mineral). Studies found that the magnitude of the loads exceeded the scale of anthropogenic and natural coastline of the permitted limits, contradicts the condition of the natural environment, focused on the conflict situation and the creation of an entirely new type of anthropogenic landscapes (aquatic, technogenic, recreational) towards development. Sea landscapes of natural conditions and ecological problems in the development of mixed-mode based on the detailed study was made possibility of natural-geographical zoning.
\end{abstract}

Keywords: Geo-Ecology, Zoning, Landscape, Nature Use

\section{Introduction}

Within the natural-geographical zoning of research coastal region, authors cover revealing, mapping and complex characterization of particular features of some specific taxonomic geographical complexes. Geographical complexes revealed as a result of the research, are individual territorial units and differ from each other as with the features characterized for natural conditions, and with hypsometrical location of landscapes and spatial disposition, as well as with geo-ecological problems, forms and scales of anthropogenic effects, character and quality of economic coverage of the regions.

Interest in geo-ecological problems of the region stand on rational (reasonable) coverage of Black Sea coast and solving the practical tasks of nature management. Namely, with the expecting collapses of natural dynamic balance connected with the long-term economic coverage of coast. Negative remakes of similar natural systems simple prove the collapse of their functioning and improper development [1]. Researches of separate components of coast and scientific results, including evaluations of modern day status of geographic - ecological aspects, analysis and prognosis, allow us to solve this geographical problem.

In the course of intensive coverage of environment of Black sea coast of Georgia, coastal system (human being natural - economy) influenced rough negative changes. It incurred collapse of dynamic balance in nature, destroying of its functioning and multiple negative results: dynamic collapse of the "seashore" system connected with the shortage of deposits; falling of coastal landscapes under 
rough anthropogenic press by intensive coverage of coastal natural potential. Aim of this study is to provide naturalgeographical zoning of coast and to research specific geoecological problems - collapse of natural system incurred by anthropogenic Influence of the coast and degradation of shores. By fulfilling the given aim, major task set by the authors about the coastal environment, is to be solved.

Major part of the Georgian population, including resort and economic infrastructure locates within $5-10 \mathrm{~km}$ zone of the Black Sea coast, being set as the major priority region [2]. Thus, the task set for rational coverage of natural resources, aims to elaborate measures of keeping modern condition, stability of the coast, including its reasonable coverage.

Modern coast is formed based on some factors, including tectonic movement [3] of crust and changes incurred by sea wave storming [4], changing of sea shore line and movement of alluvial accumulation, melting of glaciers and increasing of energetic level of sea as a result of global climate changes, etc. Thereby, long term and chaotic manner of economic coverage within the Georgian coast roughly weakened geoecologic stability (abrasion, slipping, erosion) of the coast.

Thus, intensive washing of the beaches and degradation of beach, turned into irreversible process [5], long term and chaotic manner of economic coverage of the coast roughly weakened geo-ecologic stability of the coast. Thereby, for developing social - economic growth of Georgia and sustainable development of the region, increasing of marine goods turnover is very important, meaning building of ports for deep displacement cargo ships. If this is accomplished, coast will be largely loaded (widening of port infrastructure, deepening of underwater coast, termination of deposit flows along the shore) and corresponding negative geo-ecological changes, which falls under the competence of coastal researches, including us [6]. Geo-ecological problems of the coast are neatly connected with the surface and ground water regime of the region, including global changes of current climate. For softening influence of possible climate changes on water resources, authors think it appropriate to provide refilling, keeping and regulatory measures of water resources.

\section{Study Area \& Methods}

Black Sea coast of Georgia includes coast from the River Psou and the River Chorokhi outfalls $(315 \mathrm{~km})$. Considering local physical - geographical aspects, coast was divided into four parts: 1. Northern part (Delta of the River Psou - Eastern periphery of Eshera massif - $102 \mathrm{~km}$ ); 2. North-west part (outfalls of the River Gumista and Inguri - $103 \mathrm{~km}$ ); 3. West (Outfalls of the River Inguri and Natanebi - $57 \mathrm{~km}$ ); 4. Southeast (Outfalls of the River Natanebi and Chorokhi - $53 \mathrm{~km}$ ). Coastal line of the first one is directed from north-west to south east, generally and is characterized with significant vertical separations of underwater coastal slope. There is a slim shelf line with lots of deep and steep underwater canyons (Bichvinta) [7], where pretty wide [8] shallow line is developed. Low and hilly line of the sea shore (Gantiadi Gagra) create river and sea terraces, where in between branches of rocky hills create high (up to $100 \mathrm{~m}$ ) cliffs (South tip of Arabika massive, Hilly valleys of Miusera, Akhali Atoni and Eshera). Coastal plain and vast deltas of the rivers are occupied by modern settlements (Gantiadi, Gagra, Bichvinta, Gudauta, Akhali Atoni).

On the underwater coastal slope of the second part, there are intruding outflows of deep underwater canyons (Sokhumi, Kelasura, Kodori, Inguri). Often swallow part of the beach. Low underwater coastal slope is characterized with wide shelf, though pretty deep intrusion of the underwater canyons (Inguri, Poti) is not rare. Sea shore is mainly low (Rioni Delta) and bogged up, separated by sea dunes. Relief shows sea generation [9] signs. Modern form of connate lakes (Paliastomi, Imnati, Bebesiri, Maracha) refers to the existence of the old lagoons.

Underwater slope of the far south - east coast is distinguished with many deep canyons (Batumi, Chorokhi), incurring signs of modern dynamics of the coast (swallowing of deposits) [10]. Coastal line mainly is low (Chorokhi Delta) and hilly plain, though in the areas of Tsikhisdziri, Green Cape and Sarpi high hills form sharply expressed steep cliffs near the shore line.

For researching geo-ecological signs of Black Sea coasts and region, as well as natural - geographical zoning, we have used the following research methods:

\subsection{Space and Time Method}

Provides system comprehension of micro and nano-forms of the sea coast, understanding of their disposition and spatial changes of numeric-qualitative indexes. For revealing artificial changing factors of coastal parameters (alluvium, beach, sea shore, shore flow) we have used the results of our observations [11, 12], supporting research of numeric features and time changes (separating and reforming of whole), regular changing of quality signs (collapsing of balance, lower washings), comprehension of development tendency of morpho-dynamic signs, cause and effect of occurrences and their interconnection.

\subsection{Deductive Methods}

Stands on generalization of the occurrences based on the information (changes of coasts on the shores of Sochi, Crimea, Japan, USA) about general morpho-dynamic regularity of coasts $[13,14]$;

\subsection{Multifactorial (Complex) Method}

This method allowed to reveal geo-ecological problems of economic coverage, forms and scales of anthropogenic influence of separate components and natural - territorial complexes of the coast. Presently, coast is transformed and partitioned, having own signs and features: 1. Feeding source; 2. Granulometry of alluvium and beach; 3. Sea shore and shore line; 4. Underwater coastal slope; 5. Sea regimen; 6. Anthropogenic factor. As a result of common signs of these objects, we receive the following: analog - objects - 2 from 6 with common sign; one type objects - 4 from 6 with common 
sign; similar objects 4 from 6 with common sign;

\subsection{Method of Merged Analysis and Zoning of Components}

Is used for natural - geographical zoning and it is based on landscape - genetic principle of the object research and includes the following: research of the coast components (beach, sea edge, underwater slope, sea area, coast), factors (waves, alluvium, relief), processes (litho and morphodynamics) and ecologic condition; researching of anthropogenic loads (construction of power stations and ports, withdrawing of inert materials); revealing of geo-ecologic consequences (beach washing, abrasion of shores, lowering of attraction); marking of taxonomic geo-complexes and geoecological evaluation.

\subsection{Geo-Informative Method}

This method allows to acquire and process data (geo-data) about the objects placed in the space, to determine occurrence and development tendency of geo-ecological problems, to process graphical data and to elaborate geoecologic and environment programs;

\subsection{Modeling and Balance Methods}

Allowed us to provide graphic expression of natural processes and cartographic modeling, when it is possible to record modern form and expecting changes of coastal fragments via comparison of the initial and repeated planning Balance method stands on verifying of correlation of deposit inflow-outflow and is used for defining the dynamics of beaches.

\section{Results \& Discussions}

Considering of multifactorial nature of coastal processes, research was carried out in two stages. First stage covered the research of general signs and development aspects of coastal evolution. It was proved that in earlier stage of the coast, according to the partition of the shore line and nature of beach feeding, only four dynamic system were marked out (1. Mzimta - Psou - Miusera; 2. Miusera - Kodori; 3. Kodori Rioni; 4. Rioni - Chorokhi).

Based on the petrographic analysis of the coastal constructing material and feeding sources, it was turned out that research coast line $[24,25]$ has been partitioned in two nine independent dynamic system (1. Psou - Bzyb, 2. Bzyb Bichvinta; 3. Bichvinta - Hiphsta; 4. Hiphsta - Gumista; 5. Gumista - Besleti; 6. Besleti - Kodori; 7. Kodori - Inguri; 8. Inguri - Natanebi; 9. Natanebi - Sarpi) It has become clear that differentiation of dynamic systems relevant to the earlier stage is conditioned by natural occurrences of coastal evolution (growing of deltas, approaching of capes to the shelf edge, formation of gulfs).

Detailed research of coastal processes was carried out on key research spaces (coasts) on the second stage, which was selected as follows: 1. Marking of most typical and characterizing fragment (Coast of Gumista delta) and generalization of research results (Morpho-dynamic and geoecological signs) on similar objects (Deltas of Bzyb, Kodori and Chorokhi) via extrapolation; 2. Marking of sharply significant fragment (Middle Kolchida or Kolcheti) and spreading of the research results to the entire perimeter of low coast of Kolchida. 3. Marking of less atypical key space (Gudauta bank) and using of research results for theoretical and practical purposes; 4 . Analyzing and generalizing of geoecological results (lower washings) on key parts of damaged coasts via anthropogenic mode.

First key coast falls between the outfalls of the River Gumista and the River Kelasura $(14 \mathrm{~km})$ and includes the delta of the River Gumista, perimeter of Sokhumi Cape and Gulf, seashore accumulative plain.

For the purposes of projecting commercial port and urban infrastructure of Sokhumi, searching and analyzing of wells in coastal line and bottom of water area; comparison of planning materials of the coast (1896, 1905, 1932, 1947, 1956, 1980, 1990 years) and analysis of results; observations on underwater slope of Sokhumi cape and the canyons of the River Gumista; marking of the coastal development phases; studying and analyzing of micro relief of Sokhumi (Sea generation embankments); analysis of the effect of "external blocking" in Sokhumi Gulf; elaborating measures for regulating geo - ecological condition.

Spreading of the turf $(12,13,20)$ between the sea stone and sand layers by the wells of bottom and shore of the Sokhumi Gulf coast is proved. It also made clear that, Gulf area was occupied by vast lagoon in Holocene, which was separated from the Sea with large embankment. Research results of detailed plans of sea generation embankments of Gumista Delta (1932, 1947, 1956 years) showed the growth of accumulative cape of Sokhumi (Fig. 1).

Approaching of distal part of the Cape to the shelf edge, should have incurred movement of sea shore materials towards the steep slope inclination of the shelf.

We have to look for the facts of falling of deposit in deeper layers and limitation of cape growth, in front of the cape underwater coastal slope: underwater observations and planning (Fig. 2) showed [14] us sharp critical inclination of the slope (20-250). Potholes incurred by movement of pebble-stone deposit and sludge suspension are seen on the underwater slope, made of sludge filling and beach material, with small "crowns".

Space of Gumista Delta is about $18-20 \mathrm{~km}^{2}$. Comparably wide line of Delta falls within accumulative cape of Sokhumi. On the stage of coastal formation, drying of the lagoon formed in delta isolated from water area by embankment, helped to form separate marchland fragments and connate lakes [13]. Turf layers accrued in bogged lines of lows formed between the small generations. Presently, major part is drained and modern city was constructed instead. Small nameless connate lake and marchland fragments can be seen in proximal part of the Cape.

Unlike similar perimeters, on stabile coast of Sokhumi Gulf, really significant changes were revealed in 40s of the last century. In 1942, military ship (Tanker "EMBA") and 
reinforcement dock were cast ashore on shallow slope of Sokhumi Gulf. This fact, as it was theoretically expected caused external blocking effect [12] of the shore. As a result of strong diffraction of waves, ships caused active deposition of beach materials in front for the ships and for 50 years, in "wave shadow" beach width was increased by $155 \mathrm{~m}$ ) and was spread over 43 thousand $\mathrm{m} 2$ and deposited pebble stone reached 542 thousand $\mathrm{m} 3$.

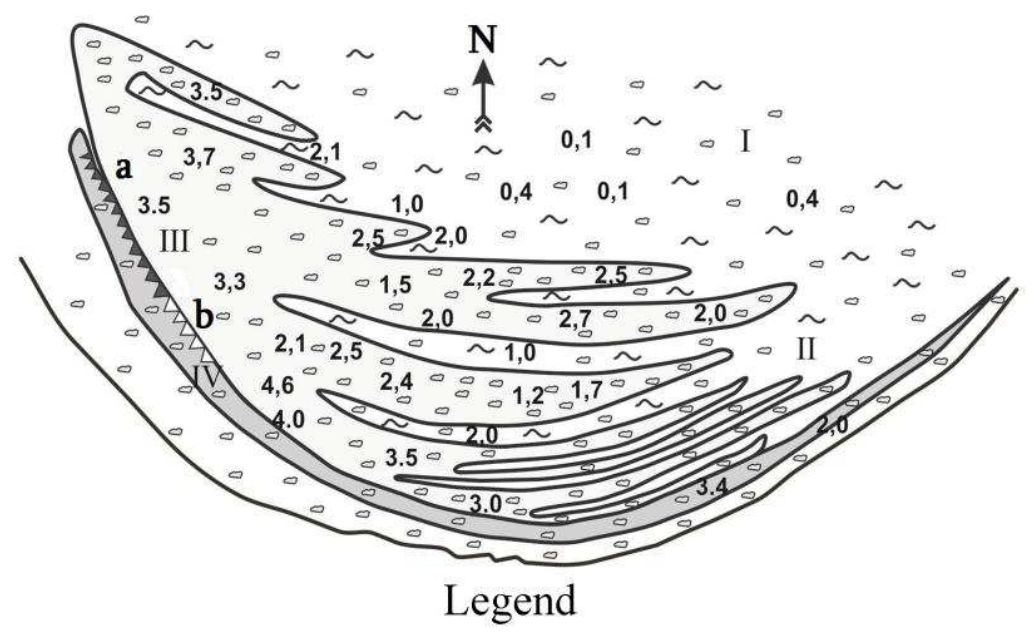

I. Peat Layer; II. Relic of embankments; III. Active (a) and Disappeared (b) scarp; IV. Modern beach line

Fig. 1. Sukhumi Cape growth tendency.

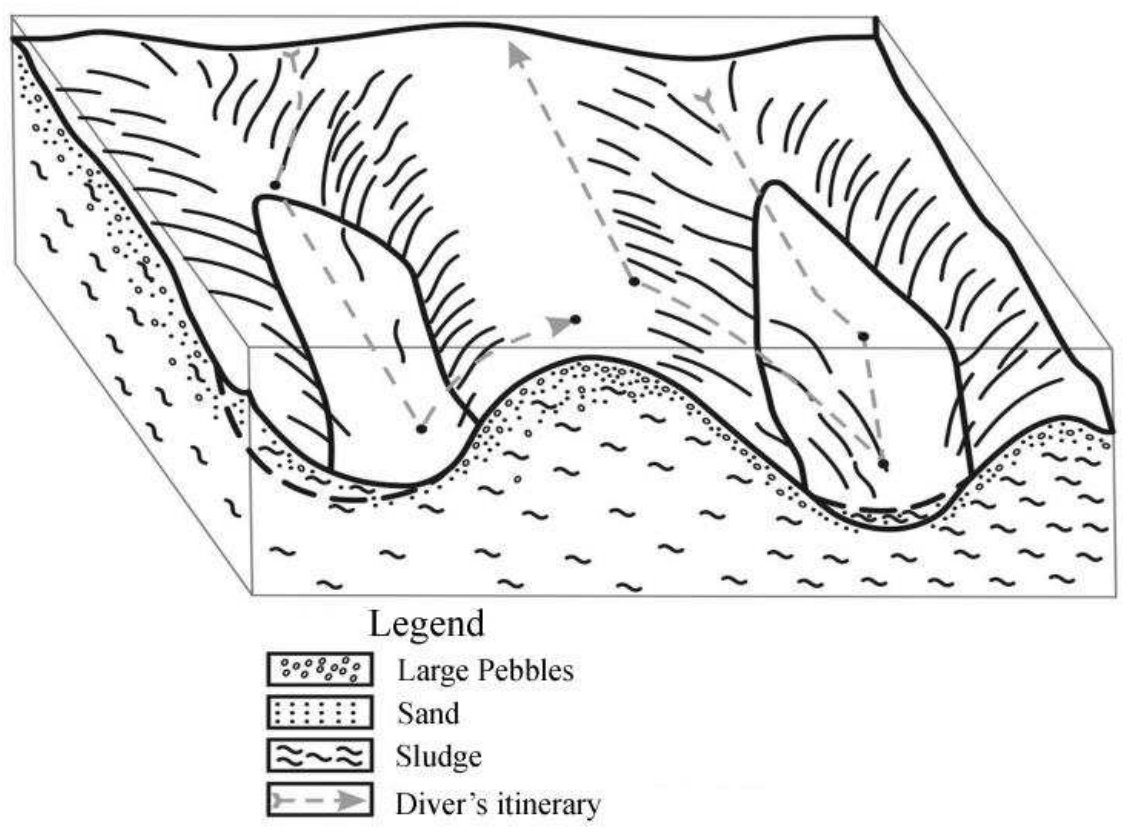

Fig. 2. Block diagram of Sukhumi cape underwater slope.

Growth of beach around ship accident area, incurred deposit shortage on the shore and active collapse of seashore fragment of the city (145 thousand $\mathrm{m}^{2}$ ). Changing of shore line incurred formation of negative geo-ecological condition - intensive abrasion of surrounding shore line [12]. Protecting of city boulevard line and constructing of $2 \mathrm{~km}$ coastprotecting wall costed 3,8 million USD.

Pretty wide and stabile beach located at Sokhumi Gulf protected the shore line very well. Though, slow decreasing of sea edge ( 0,3 meter per year) was seen in historical period as well. According to archeological remains, decreasing of shore line in the area of Sokhumi Gulf (II-XIX cc) was about 520-550 m [15]. $40 \mathrm{~m}$ bogged line of antique fortress (Dioskuria) was actively collapsing a century ago and finally it was completely swallowed up by the Sea. Similar occurrences are recorded in other fragments of research shore as well.

Thus, common aspects of the research coast - deltas of the 
Rivers Bzyb, Kodori and Chorokhi, are characterized with genetic, morphologic and dynamics signs and with spreading of similar occurrences, showing tendency of similar natural development.

Second key coast includes Middle Kolkheti sea area and mainly outflow of the River Inguri and perimeter of its surrounding water area. It is between Ganmukhuri and Kulevi, occupying 20-22 km shore. Shore line is pretty vast plain area, which is quite transformed in terms of anthropogenic loads, causing and forming new type aquatic, induced and residential anthropogenic landscapes, having passed natural, natural - anthropogenic and other modification stages. Kolchida sea line and surrounding fragments are mugged (Phichori - Kvishona, Ganmukhuri and Nakargali, Tikori - Churia) and are separated by sea generation embankments. Natural conditions and limited resources of Kolchida Region, in general do not give perspective of sustainable development. Its major part is occupied by marchlands, only small part of soil $(25-27 \%)$ is valid for cultivation. In terms of nature management, it is decreased by $18-20 \%$, annual growth of drained (secondary marching) soils are low, as well as perspective of recreational resources. Based on the low convenience of weather conditions (strong winds, high level of moisture), Kolchida sea area is less attractive for resort-tourist opportunities. More attractive is far peripheral parts of Kolchida coast (Kobuleti, Ochamchire).

Coast line is characterized with large scales of anthropogenic influence. Their transferring into natural regimen is sufficiently difficult, economically ineffective, ecologically dangerous matter of activity. Though, scientific research of perspective field and sustainable development of the region responses to time requirements. Thus, the most important perspective for sustainable development is deemed reasonable planning and realization of port infrastructure in coast line. After occupation of the Black Sea area of Georgia $(64 \%)$, perspective area of marine transport infrastructure and railway of the country was sharply decreased. Ports of Poti and Batumi cannot satisfy increased goods turnover. Thus, constructions of new ports are being discussed. Long-term practice of port constructions in other parts of the world (including seas of Georgia) (Gagra, Ochamchire, Kulevi, Poti, Batumi) showed that exploitation of capital buildings within labile, dynamic and vulnerable coastal zone often gives negative result. Major reasons include geologic, morphodynamic and landscape - ecologic aspects: 1. Possibility to pan the port with siltstone and fine sand; 2. Weak partitioning of coastal line and surrounding land; 3. Formation of shore with alluvial material and spreading of deposit flows along the shore; 4. Spatial limitation of port infrastructure by marchland fragments.

Notwithstanding the above said, relief of underwater slope of the research coast often is characterized with difficult vertical partitions and deep underwater canyons are intruded in sea shelf and coastal zone. This fact provides successful conditions for port constructing. Comparably successful conditions are in the area of old outfall of the River Inguri.
Here, beginnings of the underwater canyons are in 150-200 $\mathrm{m}$ distance from coast

Line and create deep natural entrance, defining low costs of the port construction and economic effect of exploitation (passive mobility). Port infrastructure shall have positive geo-ecologic aspects as well. It is known that, as a result of blocking the River Inguri water flow and solid eduction (277,5 thousand $\mathrm{m}^{3}$ per year) by the Hydro Power Station, decreased the volume of beach-formation fraction $(165,0$ thousand $\mathrm{m} 3$ / per year) in 4,5 - 5,0 times [16] and presently it is 29-30 thousand $\mathrm{m}^{3} /$ per year. Sustainability of the coast was more or less kept by the river deposit and flow deposit along the shore ( 20 thousand $\mathrm{m}^{3}$ per year). Negative geoecological consequences of sharp shortage of deposit in the area of the River Enguri outflow have no positive perspective in the future: decreasing of the coastal line of Gagidi, Ganmukhuri, Anaklia, Tikori is between 1-3 - 4-5 [3].

Thereby, it is known that the largest part of the deposit was swallowed by the underwater canyon directly located at the outflow of the River Inguri [17]. For avoiding this negative consequence [18], project covers stabilization of the opposite part of the head of Inguri canyon, constructing of long, deep mole $(10 \mathrm{~m})$ near canyon head, blocking of deposit flow path. Task aims both coast-protection and construction of port for deep displacement ships. Head off the deep underwater canyon located at the outflow of the River Inguri can host deep displacement ships. On the lower part of the dewatered canal of the River Inguri, it is planned to create port basin. If this artificial basin is reasonably managed, it will have great perspective: realization of $400 \mathrm{mln} \mathrm{m}^{3}$ pebble-stone in coast protection, received from processing of bottom material; arranging of sport, recreation, tourist infrastructure. Based on the historical practice of nature and culture comprehension, following complex research of the region, authors presented number of measures for elaborating projects aiming to manage natural conditions and resources reasonably:

1. Because of close location of coastal line and mineral water resources (Menji, Tsaishi), solving of conditions (distance location of natural resources and historical heritage) hindering recreation nature management of the region: a) to use Zugdidi - Mestia highway and building of airport in Mestia; b) to construct Ingiri (Zugdidi surroundings) airport and Anaklia port;

2. To create transport communication and relevant infrastructure: a) Ganmukhuri - Batumi highway along the sea; b) to connect Ganmukhuri - Anaklia - Tikori - Churia; c) to improve Svaneti highway; d) to arrange ropeway "Mountain - Sea - Seashore";

3. While elaborating resort - recreational, sanitary hygienic projects of Anaklia coast, natural factors should be considered at first place, namely: a) considering of modern tectonics in transport network, storehouse construction; b) planning of beaches, recreational parks, squares and prognosis of sea level rising tendency; d) arranging of sea complexes, studying of biotic components incurred as a result of global weather changes, revealing of negative signs of ecosystem, studying of regulation of phytoplankton and 
water ecosystem management; e) regulating of positive (comfort condition) and negative (temperature, moisture) consequences (changing of water balance, plants, secondary bogging) of marchland draining.

Third key coast (Gudauta Bank perimeter) is less typical key space in research region, thus research aims to accomplish its results as theoretically, as well as in practice. Key space is sharply atypical fragment. Studying of the bank on the second stage of the coast research [19] was conditioned for its special condition. Slope of the bank is constructed with meiotic conglomerate. It is the paleo-delta of the River Bzyb, proved by the reef of the underwater slope Underwater (diving) observations of the Gudauta Bank bottom [19] showed that, it is conglomerate plate, slightly sloped $(0,01-0,001)$, covered by break-stone and grey sand. In $200 \mathrm{~m}$, there are medium pebble-stones and boulder between the large stones. Often ruins host water plants (Cystosiera barbata) and are covered by thick serpulidae, crust or moss. In between there are left folds of Ostrea edulis, which do not inhabit here anymore, because of predatory nature of Rapana (Rapana venosa). Carbonate plates are inhabited with (Petricola lithophaga, Barnea candida, Pholas dactylus).

Studying of bank showed us that, ruins of crushed stones are spread through the bottom. On the shore, 5-7 m beach materials contain pebble-stones bored by boring mollusks, including them in the holes of limestone plates $(35-40 \mathrm{~cm})$ mollusk valves are proved. In 13-15 meters, water plants Zostera, Cystoseira, Phyllophora etc can be discovered. After each 3-4 magnitude storm, you can sea dead water plant deposits on the shore. It is clear that water plants and breakstone can be seen as on the bottom of the bank, as well as on the beach surface. Authors raise quite a natural question, whether if water plants play some role in dynamics of pebble-stone. Observation of storm waves showed that by wave force, floating ability of water plants are increasing. Observation proved that water plants are better attached with their roots to the break-stone, which are located in 5 meters deeper. For high floating abilities, stones attached to their roots are moving towards the shore. On small depth $(3-4 m)$, mechanical action of the waves is increasing and boulder removes from the roots, though storm waves cast them ashore.

Thus, mobility of pebble stone deposits from bottom to the shore and feeding of the beach is proved. As the occurrence is very important, volume of the feeding source was determined via balance method. For these

Purposes, within the coastal zone of key space $(6 \mathrm{~km})$ inflows and outflows of deposits were calculated. Annual inflow: 1. Alluvium of the rivers $\left(6000 \mathrm{~m}^{3}\right)$ and 2 . Bottom material $\left(4000 \mathrm{~m}^{3}\right)$. Outflow: 1. Accumulation on the shore $\left(5000 \mathrm{~m}^{3}\right)$ and 2 . Grinding of pebble-stones $\left(5000 \mathrm{~m}^{3}\right)$.

Balance report shows: on the coast of the kea space, keeping of balance between the volumes of natural inflow of the beach materials from the bottom, its inflow and grinding.

Inflowing of the deposit from underwater slope to the beach is pretty familiar process. It is recorded on the shores of Tarkhankut, Absheron and Estonia. Thus, outflow of the deposit from the bottom is proved process.

It is important for both theoretical and practical point of view: existence system interaction of underwater and surface beach materials, turned wave power in favor of human being (artificial beaches). This allowed to extract deposit from small depth (4-5m) (coast protection of Kobuleti, Poti, Sokhumi).

Fourth key coastal parts includes shores damaged anthropogenically, showing negative geo-ecological consequences (lower washings, abrasion of major shores). On the key parts of the coasts under economic pressure, negative geo-ecological consequences are conditioned by the construction processes of port infrastructure and improper exploitation, unreasonable coast-protection "concrete policy", intensive extracting of beach materials from the sea shores. Negative consequences of economic activities on the shores are spread generally. World practice showed that $[21,24]$ geo-ecological aspects developed as a consequence of strong anthropogenic pressure affecting the shores of the seas and oceans (Japan, USA, Russia) shows undesirable signs. For clarification, we shall discuss some of them:

1. Construction of port in Old Gagra, within 6-7 km perimeter, slowing of "lower washing" was followed by dyke construction and formation of new washing parts; for the purposes of railway contour, to the west of Gagra Gulf (surroundings of the village Grebeshok), deposit flow along the shore was cut by dyke series (32 dykes and 3 wave breaker). Later, dyke series was filled with deposit material (30 thousand $\mathrm{m}^{3} /$ per year) [22]. Notwithstanding this, "lower washing" was spread over 5-6 km; similar occurrence was recorded in the surroundings of Gagra, Gudauta, Akhali Atoni, Ochamchire. Stopping of local abrasion via reinforcement dyke series and shaped constructions (tetrapods, dipods), including wave breakers, was followed by formation of new sections of lower washings";

2. Deposit flow $(69 \mathrm{~km})$ of the Kodori Dynamic system (seashore perimeter of the River Kodori and the River Inguri), was cut by the port mole near Ochamchire. Thus, shore was decreased with 250 in some sections as a result of "lower washings". Arrangement of coast-protection walls and dyke series for protecting the city were followed by formation of "lower washing" sections. In the north area of the port mole, pretty wide beach was formed on the left section of the River Mokvi outflow. Similar occurrences were recorded within the areas of Poti and Batumi ports. Especially, strong negative geo-ecological consequences were recorded in terms of construction and exploitation of Poti Port. On the north Nabada section of Port, 200-250 m sand beach was formed and in the south, in surroundings of the great island, coast line was decreased in $800 \mathrm{~m}$;

3. Notwithstanding that alluvium was proved as the major feeding source of the beach, because of the construction of the Inguri Power Station (1972), major part of water flow was transferred into the canal of the River Eristskali; later was used as channel and its intrusion in coastal water area formed "dyke effect" in the south of Ochamchire (Gali 
Municipality, causing active abrasion of the major coast. On the right zone of the "outflow" of the River Eristskhali wide (80-110m) beach was formed, and coastal line was decreased in $12-15 \mathrm{~m} / \mathrm{yy}$ on the left section. Power of deposit flow along the show fell down 2 times and actively decreases. Because of rough decreasing of the beach feeding material (4-5 times), Kolchida coast decreases in $2-5 \mathrm{~m} /$ per year [16];

4. Constructing of power station on the River Chorokhi on the territory of Turkey, provides negative geo-ecological affect on the coast of Achara - Guria, putting it under danger [23]. Village Adlia (Achara) is especially under danger, where beach washing and decreasing of the shores is more than 5-7 meters annually.

Thus, reviewed material and its analysis shows that, in terms of coverage and exploitation of coastal region, they had gone under strong and impressive changes. Based on the clear image of the changes and differentiation, geo-ecological features of the coasts, natural conditions, landscape development and detailed research of geo-ecological problems, provided natural - geographical zoning. Taxonomic zoning units are as follows (Fig. 3):

Region - sharply expressed geotectonic unit, with different modern tectonic, with natural conditions and resources, homogenous geo-ecological problems;

Subregion - regional geomorphologic unit, with nonhomogenous natural factors (relief, air, hydrography), similarity of geo-ecological processes;

District - comparably local territorial unit, with comparably similar natural conditions and geodynamic processes;

Subdistrict - low regional unit, with homogenous relief and similarity of natural processes;

Area - local territorial unit with micro relief forms and priority development of one of the elemental processes.

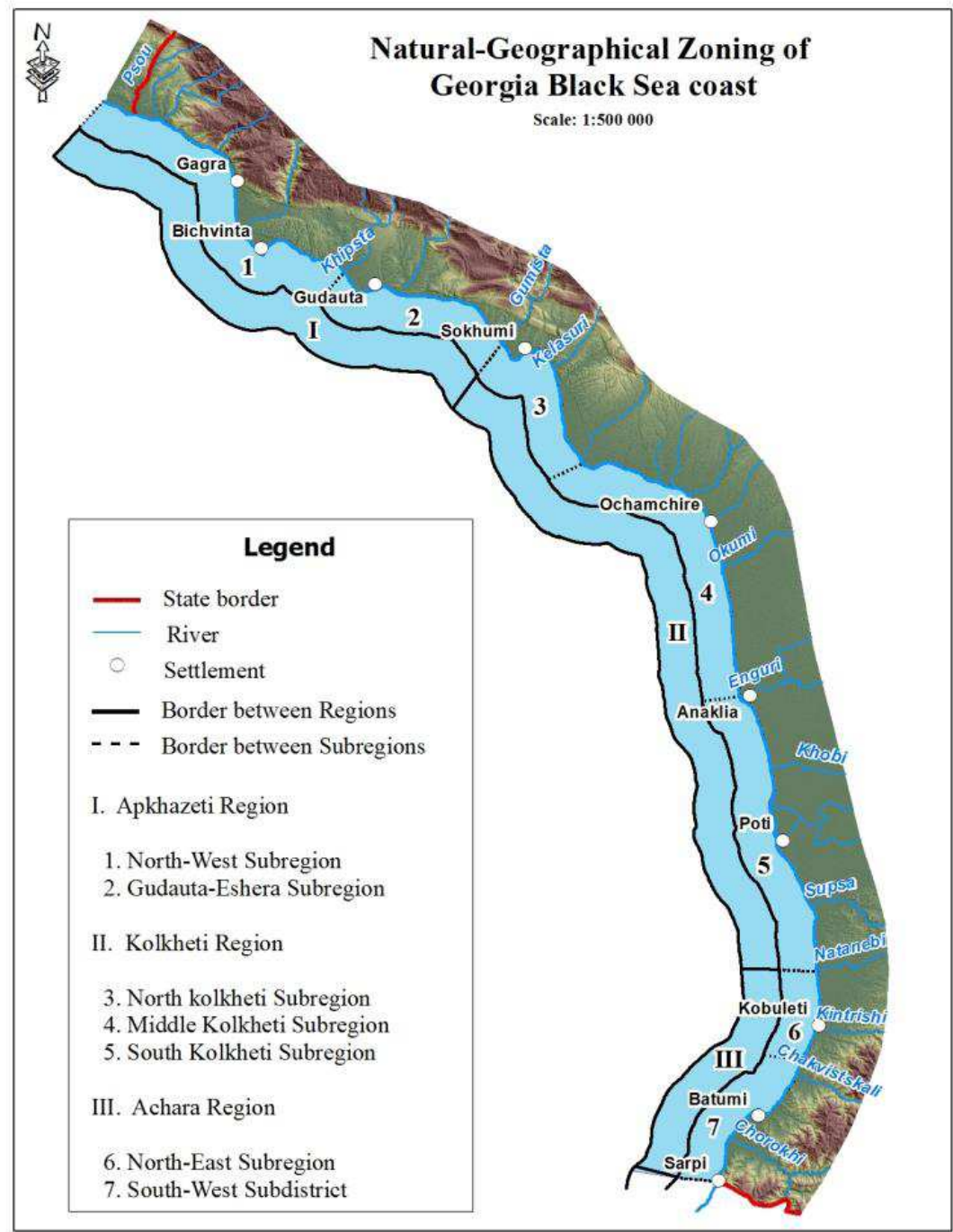

Fig. 3. Natural-Geographical Zoning of Georgia Black Sea coast (Within the Subregions it is Separated: 19 districts, 42 subdistricts, 103 area (because of research scale it was impossible mapping of relatively thin taxonomic units - Districts, Subdistricts, Area).

\section{Conclusion}

1. Environment object regulation and management measures, including some economical problems - elaboration and realization of reasonable projects of port infrastructure (Anaklia Port) are offered for the optimization of sanitary 
pollution of dewatered sections (lower flow of Inguri), as a result of construction of power stations, remaking of river canals and extracting of inert materials from the beach, negative geo-ecological consequences as a result of strong anthropogenic pressure of the low and vast plain and underwater coastal slope of Kolchida.

2. Based on comparing of common and differentiating morphological - dynamic features of the coasts (feeding source, granulometry of deposit, coastal relief, underwater slope, sea regimen) the following can be marked out:

A). More than four from six with common signs i.e. Similar objects: according to the genetic - tectonic and morphologic similarities, they are grouped in 2 parts:

A) Coasts of accumulative plains of alluvium - delta generation (Psou-Mzimta Delta - Bzyb Delta - Sokhumi Cape - Kodori Delta - Rioni Delta - Chorokhi Delta);

B) Coasts of hilly seashore massifs (Tkhemi - Miusera Eshera - Green Cape - Tsikhisdziri - Gonio - Sarpi);

B) Four from six with common signs i.e. One type objects: plane and narrow plains sea shore parameters (Gantiadi Gagra - Bombora Roadstead - Bichvinta Bay - Gudauta Bay Kindgi-Kobuleti-Kakhaberi);

C) Two from six with common signs i.e. Analog - objects: low coasts of vast and plane underwater slope, more or less showing bottom feeding: Gudauta - Ochamchire - Middle Kolchida;

3. Natural inflow of materials (break stone), attached to the roots of the water plants, formed as a result of biological drying (boring of underwater stones by boring mollusks) in underwater bottom constructed with meiotic conglomerate of Gudauta Bank and its role in feeding of the beach is proved. Launching it into practice (filling of beach shortage with artificial inflow of deposit) is pretty attractive activity, being economically effective, based on ecologically safe technology.

\section{Acknowledgements}

This research would not have been possible without the support of many people and also without using many scientific researches done by the staff of Sokhumi State University and the Department of Geography (Faculty of Exact and Natural Sciences) of Ivane Javakhishvili Tbilisi State University. Authors of the work express their gratitude to all them.

\section{References}

[1] M. Alpenidze, Z. Seperteladze and E. Davitaia (2013) Landscape and environmental problems nature manajement Black Sea Coast Kolkhida (the effects, perspective). I International Conference "Kolkheti Lowland Water Ecosystems - Protection and Efficient Use", Workbook, pp. 132-135.

[2] M. Alpenidze and Z. Lomtatidze Black Sea: Abiotioc and Biotic process dynamic. Abiotic Factors. Part 1. Apkhazeti National Academy of Sciences, Tbilisi, 2011, pp. 235.
[3] N. Dunaev The contribution of recent tectonics in the state of the sea coast. In the coll. Seashores - evolution, ecology, economy. Proceedings of XXIV International Coast Conference. Tuapse, 1-6 X, 2012, pp. 152-155.

[4] N. Fokina. Anthropogenic factors abrasion processes. In: Construction and technological safety. Vol. 15-16, Simferopol, 2006, pp. 138-142.

[5] Kolkhida lowland: Scientific background and development. Moscow, 1990, -248 p.

[6] M. Alpenidze and G. Lominadze. Where and How should built Port in Anaklia "Georgia and World" \# 21 (256), 11-17 June, Tbilisi, 2014, pp. 18-19http://www.geworld.ge/View.php? Artid=5966\&lang=ge

[7] V. Zenkovich. Research of the coastal zone of the Black Sea within Georgia. Proc: Natural foundations coastal protection. // under. Ed. V. P Zenkovich, E.I Ignatov, S.A. Lukyanova. "Nauka", Moscow, 1987, pp. 45-51

[8] M. Alpenidze, Z. Seperteladze and E. Davitaia Black Sea rational nature landscape-ecological research and regulationmanagement of anthropogenic processes (on example of Georgia). Collected papers: "Current Problems of Mountainous Regions Geography", Tbilisi, 2008, pp. 329-341.

[9] M. Alpenidze and E. Davitaia Kolkheti Black Sea rational nature use regional and geographical issues. "Science and Modernity", Tbilisi, Science, 2003, pp. 135-142.

[10] G. Russo and S. Khorava. Coastal zone protection with artificial beaches (Kobulety city, Georgia) http://coruna.coastdyn.ru/iccal/pub/ russo.pdf;

[11] M. Alpenidze. Latest developments of Sukhumi district coastline. Msg. ANGSSR, Volume 90, № 2, Tbilisi, 1978, pp. 397-399.

[12] M. Alpenidze. Features of Sukhumi district. Geomorphology, Moscow, № 3, 1983, pp. 56-61.

[13] V. Menshikov, V. Peshkov and M. Alpenidze Some structural features of submarine canyons in the area of Cape Sukhumi. Msg. Academy of Sciences of the Georgian SSR, 95, № 3, Tbilisi, 1979, pp. 637-640.

[14] I. Voronov about dynamics of the coast of Sukhumi Bay in historic times. - In Proc. Of young scientists - historians of Abkhazia. Sukhumi, "Alashara", 1974, pp. 24-38.

[15] Sh. Jaoshvili Black Sea Rivers. European Agency for Environmental Protection. Tbilisi, 2003, - 186 p.

[16] G. Lominadze, N. Megreli and G. Russo. Change of Black Sea coastal area (central part of Kolkhida, 1976-2002) under influence of man-induced factors. Change of Environment at the Turn of the Millennium. Proceedings of International Internet Conference. Tbilisi-Moscow, 2006, pp. 133-139.

[17] V. Zenkovich. Expected changes in the north sea coast of Kolkheti. Academy of Sciences of the Georgian SSR 83, №3, Tbilisi, 1976, pp. 637-640.

[18] M. Alpenidze. Bottom power long shore sediment. Geomorphology, № 2, Moscow, 1985, pp. 65-70.

[19] M. Alpenidze. Formation and development of Sukhumi alluvial plain. Geography and modern environmental problems // Proceedings E-Conference (25 May - 25 June), Tbilisi: SGU, 2014, pp. 75-91. 
[20] V. Zenkovich. From foreign experience marine coastal protection. Proc.: Natural foundations coastal protection. "Nauka", Moscow, 1987, pp. 149-153.

[21] A. Peshkov. Artificial pebble beaches in the marine coastal protection. USSR Academy of Sciences. The Commission on the World Ocean. Nauka, Moscow, 1987, pp. 165-171.

[22] Sh. Jaoshvili What may happen to the Adjarian Coast after construction of the Dams on the Chorokhi river. 2000, http://www.cenn.org/

Magazine1/Magazine3/whatmayhappenrus.html
[23] M. Orlova. Sea coast of the Crimea as a resource for recreation (on example of the coast of Zap. Crimea). Author. Dissertation of candidate of Geographical Science, Moscow, 2010, 26 p.

[24] A. Kiknadze. Application of the method to the lithological study of the dynamics of the coastal zone (on example of the Black Sea coast). Dissertation of candidate of Geographical Science, Moscow State University, 1970, -17 p.

[25] A. Kiknadze. Dynamical systems and sediment budget along the Black Sea coast of Georgia. Proc.: Man and the environment, Sukhumi, “Alashara”, 1977, pp. 59-67. 